\title{
Mitigation History of the Industrial Hg Contamination in the Nura River Watershed of the Republic of Kazakhstan: Evolution of an Adaptive Management Approach
}

\author{
Dinara Tamabayeva (Corresponding author) \\ Civil and Environmental Engineering, University of Alaska Fairbanks \\ Fairbanks, Alaska 99775, United States \\ Tel: 778-628-4727Ｅ-mail: dtamabayeva@gmail.com \\ Lawrence Duffy \\ Department of Chemistry and Biochemistry, University of Alaska Fairbanks \\ Fairbanks, Alaska 99775-6160, United States \\ Tel: 907-474-7525 E-mail: 1kduffy@alaska.edu
}

Philip A. Loring
Water and Environmental Research Center, University of Alaska Fairbanks

Fairbanks, Alaska 99775, United States

Tel: 907-474-7163Ｅ-mail: ploring@alaska.edu

\begin{abstract}
David Barnes
Department of Civil and Environmental Engineering, University of Alaska Fairbanks

Fairbanks, Alaska 99775, United States

Tel: 907-474-6126_E-mail: dlbarnes@alaska.edu
\end{abstract}

Received: April 3, 2013 Accepted: April 15, 2013

doi:10.5296/emsd.v2i1.3484 URL: http://dx.doi.org/10.5296/emsd.v2i1.3484 


\section{Abstract}

In this paper, we briefly describe the clean-up and remediation of a major watershed in Kazakhstan, the Nura River, that was impacted by rapid industrial development during the Soviet era, leaving a legacy of mercury pollution impacting hundreds of thousands of people. Fresh waters, including rivers, lakes, glaciers, groundwater, man-made reservoirs and canals represent less than 3 percent of the earth's water. Watersheds are closely linked ecosystems that are natural units of analysis and management. Over the last century, the use of freshwater systems has grown at an unprecedented rate to supply and support industrial and agricultural production. Remediation of damaged watersheds and sustainable water management are important tools to minimize the impact of the human activities, especially industrial activities, on the ecosystem services provided by a healthy watershed. Based on engineering reports and data, we discuss the importance of adaptive management strategies, flexibility, and place-based $\mathrm{Hg}$ remediation criteria, as well as the value of stakeholder input in a polycentric project management approach.

Keywords: Mitigation, Remediation, Mercury, Hg, Watershed, Nura River, Kazakhstan

\section{Introduction}

Rivers are a major component of a drainage system. Watershed describes a drainage basin, within which sources of pollution can be introduced and dispersed across a landscape and ecosystem (Manahan, 2011; Dunlap et al, 2011; Loring et al, 2010). In the decades following World War II, the demand for material goods increased the use of raw materials manufactured into products, a major aspect of a material cycle (Maxwell, 2009; Manahan, 1999). Processes within a material cycle can create toxic wastes that are hazardous to both workers and the population in general. During this post war growth, industrial pollution created by manufacturing also slowly spread to developing countries such as Kazakhstan.

Thus, in August 1950, as part of the industrialization of the Republic of Kazakhstan in the city of Temirtau within the Karaganda Oblast (KZ unit of administration), the Karaganda Synthetic Rubber Factory commenced operations, which produced a variety of products, including acetaldehyde, a key component for another process in the production of synthetic rubber.

This article is about the case of the river mercury contamination in Kazakhstan and the methods used for its remediation. It tells about the background of the contamination, basic solutions of the clean-up design, and the difficulties and other aspects of the reality that the specialists had to face during the project implementation.

This Acetaldehyde Unit used sulfuric acid and a sulfate salt of mercury (II) to catalyze the hydration of acetylene to produce acetaldehyde, a key component for another process in the production of synthetic rubber. The Acetaldehyde Unit had an initial production design capacity of 43,200 tons of acetaldehyde per year, increasing production to 76,500 tons by 1975. In the early 1990s, the plant became the state controlled joint stock company "Karbide". By 1995 the output had been reduced to 36,000 tons per year due to a decreased market for acetaldehyde. After the Soviet Union collapsed, the industrial development was suspended, 
and the production at the acetaldehyde unit eventually ended in 1997. In 1998 "Karbide" JSC was split into three independent plants, and the acetaldehyde unit was retained by the state-owned "Karbide" JSC.

Mercury was essential to the process of acetaldehyde production. Some of the mercury was transformed into metallic mercury $\left(\mathrm{Hg}^{\circ}\right)$ and organic mercury compounds such as $\mathrm{CH}_{3} \mathrm{Hg}$. Mercury escaped the plant either as sludge or as residue from the distillation unit where $\mathrm{Hg}^{\circ}$ would be lost to the atmosphere. Distillation of the mercury containing sludge during the acid regeneration process resulted in a treated sludge with reduced $\mathrm{Hg}$ amount which was released to the atmosphere. A significant amount of mercury also entered the "Karbide" JSC plant waste water stream. The plant's waste water treatment was equipped with biological filter beds, followed by chlorination in treatment tanks. After the sludge from the biofilters settled, overflow was discharged to the main drain (which discharged all the waste water from Temirtau) through an underground collecting channel which eventually emptied into the Nura River. These Hg-containing effulents often leave substantial quantities of $\mathrm{Hg}$ in the sediment of rivers and lakes (Yen, 1999, Maxwell, 2009).

Tank sludge, which accumulated in the treatment tanks, was deposited onto a sludge drying bed. Until 1969 this sludge, containing $\mathrm{Hg}$, was discharged as a waste into an undrained depression known as the Zhaur Swamp. In 1969, sludge filtration beds were constructed at the "Karbide" JSC site. Throughout the years of plant operations, mercury-containing sludge had also been deposited in the 'old' ash dump of the KarGRES-1 thermal power plant, located on the banks of the Nura River. There were numerous failures in the KarGRES-1 ash dump, which led to periodic uncontrolled discharges of the ash and mercury-containing sludge to the Nura River.

\subsection{The Nura River and Zhaur Swamp Mercury Clean-up Project in Kazakhstan}

Mercury released from industrial processes has created a legacy of toxicity to rivers and lakes worldwide (Swartz et al, 1994). For the Nura River community, this risk was coming from a variety of sources which were a legacy of the old Soviet inspired industrial development model that was implemented without proper local or national stakeholder input. The current rural residents living along the Nura River were exposed to $\mathrm{Hg}$ because the Nura River is a major source of their drinking water. Fishing and crop irrigation also led to $\mathrm{Hg}$ exposure as methyl mercury was magnified up the food chain.

As shown in the Figure 1, the water supply system of Kazakhstan is administratively divided into administrative river basins. The Nura River belongs to the Nura-Sarysu River Basin and watershed. The water supply to residents of Temirtau and Karaganda, major cities of the watershed, comes from a combination of the Irtysh-Karaganda Canal, groundwater sources and the Nura River. 


\section{Macrothink}

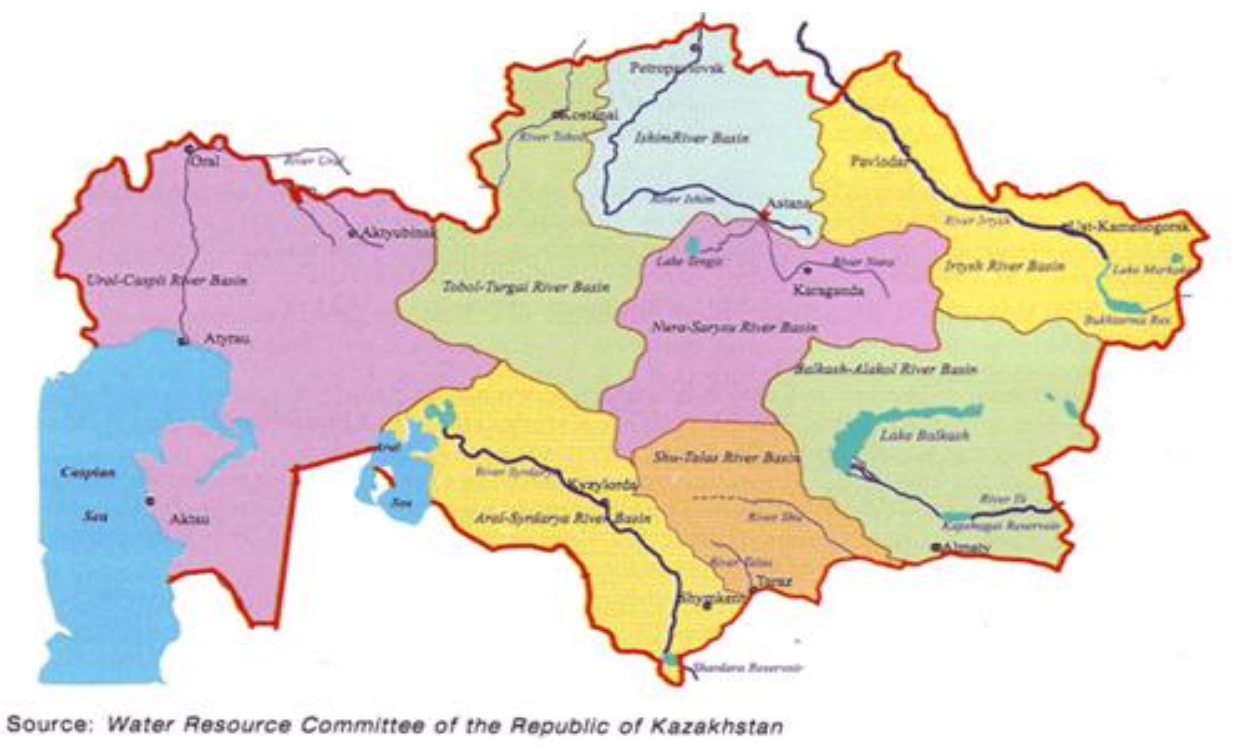

Figure 1. Map of the main river-basins of Kazakhstan, (Committee for Water Resources of the Republic of Kazakhstan 2006)

As the years passed towards the 2000s, the demand for fresh water increased with industrialization and with the Nura River becoming a second water source for the residents of the city of Astana, the capital of the Republic of Kazakhstan. Besides demand for drinking water, the need also grew for water to irrigate more agricultural land and to preserve the fishery habitat. The Yntumak reservoir was also contaminated by the $\mathrm{Hg}$ waste water from the acetaldehyde process plant and could not sustain the fishery due to the presence of increasingly contaminated sediments. Although the $\mathrm{Hg}$ concentration in the majority of the Yntumak reservoir fish was below the Kazakhstan water quality safety norms $(0.3 \mathrm{mg} / \mathrm{kg} \mathrm{Hg}$ for non-predatory fish, $0.6 \mathrm{mg} / \mathrm{kg}$ for predatory fish) more than $7 \%$ of sampled fish had mercury concentration exceeding the European Union (EU) norms $(0.5 \mathrm{mg} / \mathrm{kg}$ ) (EC Commission, 2006). An advisory for the fishery was released that limited the number of recommended fish meals per week. It was also advised that children and pregnant women should not eat the fish caught in the Nura River below Temirtau City, (Figure 2), including the Yntumak Reservoir.

Another issue that developed was related to the growing $\mathrm{Hg}$ threat to the international landscape and wildlife conservation reserves located in the region. The Nura River flows into the Tengiz Lake, (Figure 1) located in the Korgaldzhyn National Nature Reserve, a World Heritage Site of the United Nations Educational, Scientific and Cultural Organization (UNESCO). This is the northern habitat for pink flamingos in Kazakhstan, a threatened species which is protected by UNESCO. The recreational and natural uses of the Korgaldzhyn Reserve have an important cultural value to both the local inhabitants and the international community (Posch \& Partners, 2007).

\subsection{Social Impacts and Economic Disparities}

Environmental degradation has effects on social economics systems which can result in health and nutrition dispartities (Trainor et al, 2009; Loring and Duffy, 2011; Dunlap et al 


\section{Macrothink}

2011). As we discuss here, $\mathrm{Hg}$ pollution of the Nura Watershed impacted the social system in the region too. The clean up project design proposed a plan that would create social risks that were connected with the land use and land compensation. New legislation from Kazakhstani authorities concerning the degraded land, would in turn, impact the original clean-up design. Since the creation of the landfill site would take current agricultural land out of use, and restrict the use of other agricultural areas, the design was revised, illustrating the growing use of adaptive management by governance for environmental projects. The use of adaptive management also illustrates a new use of stakeholder opinion. Stakeholder involvement has been successful when local knowlwdge is used at planning, operational and evolution stages (Burger, et al, 2007). For individual risk communication, home gardens with $\mathrm{Hg}$ contamination would be remediated, when additional monitoring identified them as a source of home grown food in which $\mathrm{Hg}$ had been detected.

\subsection{Design Concept of the Nura River Site Clean-up Project}

The design of the project evolved as implementation began. After an initial overall design was approved, the Nura River Clean-up Project was organized into four basic components according to the sequence of its construction. First, the Project would construct a disposal facility for the reception of the mercury contaminated wastes, i.e. a landfill planned to cover an area of 168.94 ha. Second, the major sources of the mercury contamination would be eliminated by dismantling the Karbide factory, and third, the associated sites that represented additional sources of mercury would be treated. Lastly, the clean-up of the Nura riverbed would have sediment removed. The land tract allocated for the landfill development would cover an area of 168.94 ha. Figure 2 shows the location of the landfill and the major source sites of the mercury.

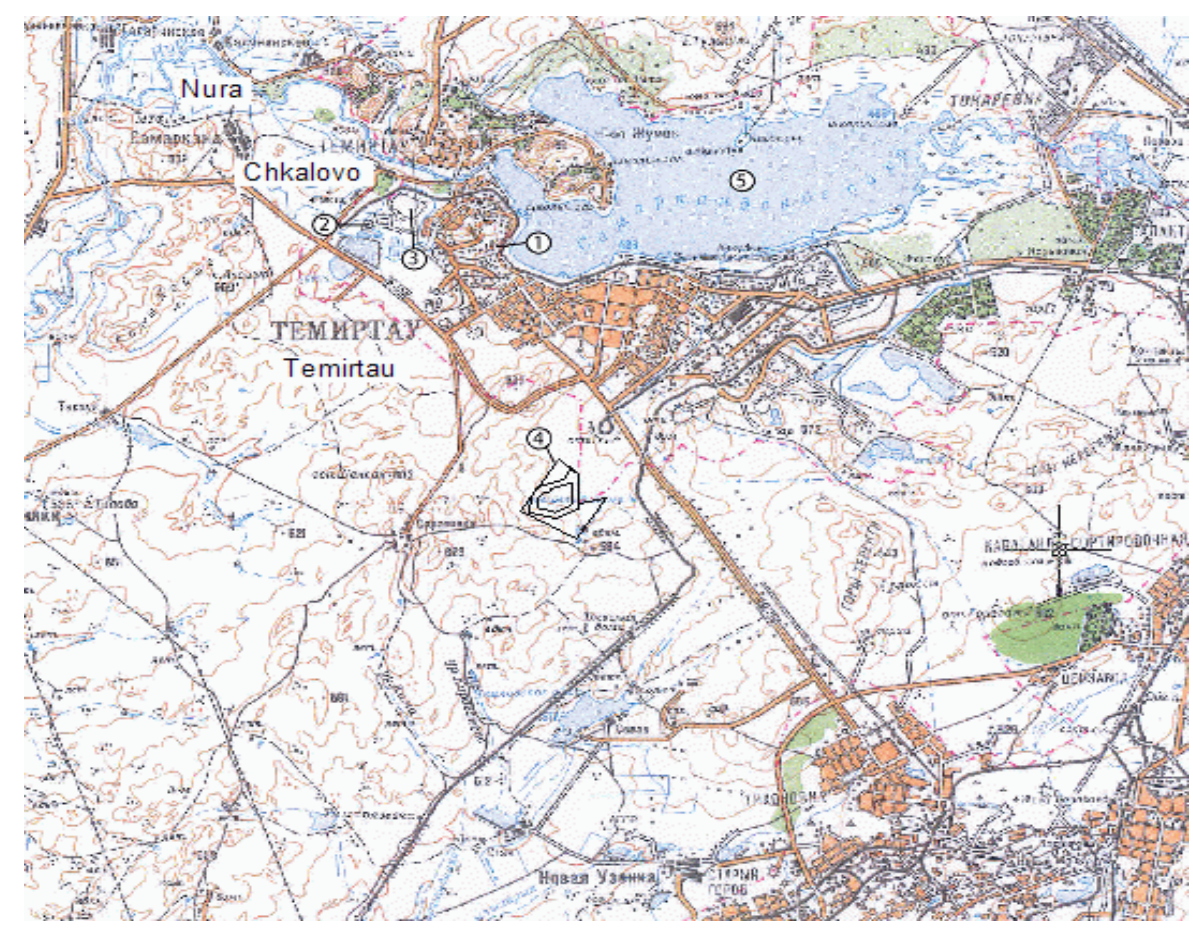

Figure 2. Map of the Nura River Mercury Clean-up Project area 
1) Karbide factory site,

2) WWTP (Waste Water Treatment Plants),

3) KarGRES-1 Old Ash Dump,

4) Apan Site for the Landfill construction,

5) Samarkand Reservoir

\section{Clean-up Methods}

During this renewal phase, the $\mathrm{Hg}$ sources generated from the project were divided into two classifications:

- $\quad$ Upstream stream clean-up component (Karbide factory and associated sites); and

- $\quad$ Downstream clean-up area (the Nura River and Zhaur Swamp).

In each classification, the wastes to be disposed on the Apan landfill (Figure 2, Site 4) were further categorized in accordance with their hazard class. The landfill was organized into units called cells which allowed a record of where the different types of hazards were stored. This allowed for future project managers to solve problems that may develop.

The goal of the Nura river-bed clean-up was to remove all mercury contaminated material from the river section between Samarkand Reservoir and Rostovka village that showed concentrations of mercury higher than the designed clean-up criteria, which was based on European environmental health standards (EC Commission, 2006). However, a comprehensive monitoring program was not performed immediately prior to the excavation before any permanent changes in the morphology of the river system were caused by local erosion or changing topology. Eventually, an adaptive management approach created a program to ensure maximum accuracy of the removal and storage information. $\mathrm{Hg}$ sampling was performed just before the excavation began in a limited area, as the excavation and sampling activities worked their way downstream, beginning upstream at the Samarkand Reservoir Dam (figure 2, Site 5). Thus, out of every 10th truck load leaving the transfer station, a sample was taken for analysis by the Supervision Engineer's team. The engineer took samples at the bottom and sides of the excavated area. If the analyses showed contamination below the corresponding clean-up criteria, the Engineer declared the area as "clean", and the landscaping and re-vegetation measures were begun. Otherwise, excavation work continued and the procedure repeated. (Posch \& Partners et al., 2005).

Another example of the adaptive management approach, for the the Nura River and the Zhaur Swamp, is illustrated by the plan which was modified to add excavation and dumping for the entire clean-up of the Nura River and the Zhaur Swamp (Figure 2). Conventional excavation and landfill dumping was the only safe and economic method for a controlled and sustainable remediation of the Nura River pollution. This adaptive design modification was prudent 
because it could be executed with local resources, as well as leaving open options for future treatment and management.

To facilitate effective communication among personnel working in different aspects of the project, the work areas were generally divided into "Black (contaminated) Zones" and "White (uncontaminated or already cleaned) Zones". The contaminated material in an area defined as a Black Zone was excavated and transported to a Transfer Station area and off-loaded there. On the clean side of the Transfer Station, the material was loaded on large trucks which then transported the material to the landfill site's White Zone. The excavated material was weighed and sampled. The trucks were covered with tarpaulin during transportation, and upon reaching the landfill the trucks were weighed again on the landfill's scale. In addition, at isolated and remote sites in the clean-up region, temporary transfer stations with mobile equipment were set up, and then moved from one site to the next, as "mobile Black Zones".

The size of the area to be dredged, led to a design plan that chose swimming hydraulic dredging equipment because of its relatively small size which can be easily transported. The swimming dredger started excavation at the effluent of the old main drain (Figure 2). Excavation was carried out with different types of submersed cutter heads in order to adapt to the variety of encountered material and to avoid turbidity in the river. A sediment water mixture (solids between 10-20\%) was pumped through a pipeline to dewatering lagoons. Three partioned dewatering lagoons of approx. $300 \mathrm{~m}$ diameter and 1.5 meter depth were built as ponds in black zones. The pumping was done by the hydraulic dredger without additional booster stations. The hydraulic dredger moved step by step downstream and the flexible, small diameter pipeline was moved accordingly. The pipeline was always laid to the nearest dewatering lagoon. (Posch \& Partners et al., 2007)

\section{Results}

The Nura River Clean-up Project had not only brought the practical benefits in the form of cleaner water and minimization of mercury pollution risks in the environment of the Nura river valley, but it formed grounds for applying new management methods.

\subsection{Remediation of Nura River Watershed as an Adaptive Cycle}

The goal of remediation management of a watershed should be to re-establish the resilient nature of an ecosystem. An ecosystem provides multiple ecosystem services to society, one of which, in this case, is fresh water. The benefits of a healthy water provisioning service is improved community health and waste management. Society in general and community health specifically, benefits from healthy and sustainable water systems (Gleick et al 2007). A disturbance shapes the changes in the structure and functioning of ecosystems, often reducing its resilience and increasing its vulnerability to other stresses (Chapin et al, 2009). As described above, the industrialization and resulting pollution of the Nura River watershed changed both the resource availability and physical structure of the water system. The changing capacity of ecosystem services can be modeled as an adaptive cycle (Figure 3 ). 


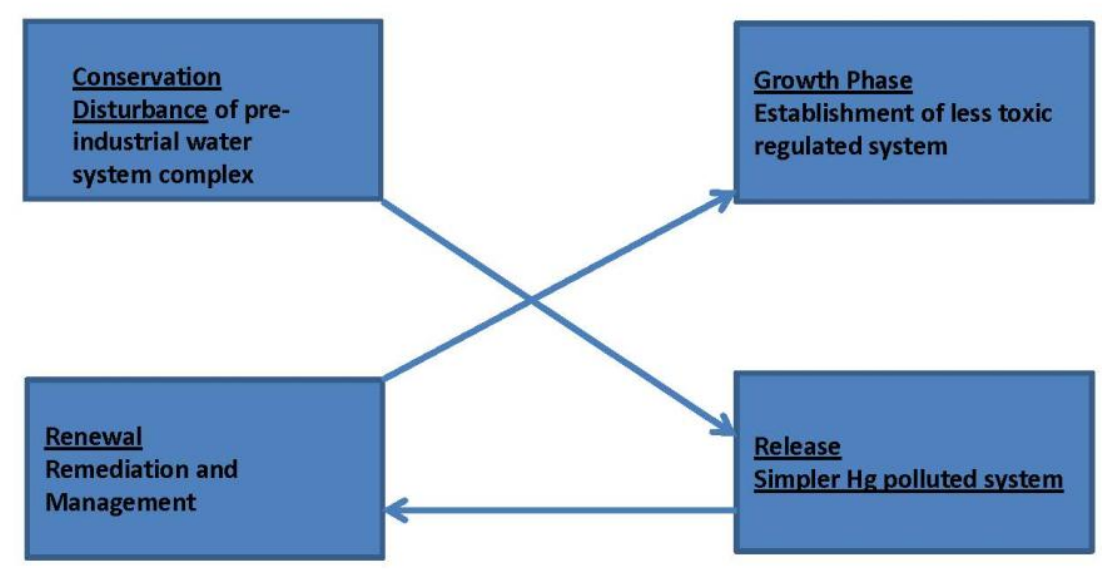

Figure 3. Nura River Watershed Adaptive Cycle

Complex socio-ecological systems are typically able to adapt to a disturbance over time, commonly called the adaptive cycle (Gunderson and Holling, 2002). The so-called release phase caused by the stress is followed by a renewal phase. In Kazakhstan, industrialization in the watershed and related growth or expansion of industry was the stress that released a stable non-contaminated state to a polluted water state. Kazakhstan is currently experiencing a series of "booms" associated with natural resource development of oil and minerals (Watters, 2009). Chemical pollution of surface and ground water was of increasing concern to stakeholders and necessitated an adaptive management approach. Exposure to toxic metals like mercury in the Nura River case are linked in various studies to a range of chronic diseases, including cancer, birth defects, heart disease, diabetes, and neurodegeneration (Loring and Duffy, 2011). Cleaning water of these compounds is very expensive; and unfortunately, the value of reducing impacts to functioning natural water resources is not often recognized until they are degraded (Chapin et al, 2009).

The remediation clean-up project on the Nura River demonstrates a successful improvement in resilience by producing new conditions which support active transformation to a cleaner, steady state (Figure 3). A key consideration now is"how clean?" and "how flexible?" should remediation criteria be?

An important aspect in providing a safe environment for people and their activities is the control of toxic substances in the water supply (Manahan, 2009). This is accomplished through monitoring and comparing the obtained data with the criteria specified in the official guidelines, after stakeholder input (Loring and Duffy, 2011). Such criteria values of toxic substances, particularly mercury, are derived based on regional background contamination level, historical circumstances, and overall scientific research as knowledge evolved during a project. However, as practice shows, unilateral and overly strict values make it impossible to reach optimal and realistic decisions on clean-up activities. Here, the case study of the Nura River Mercury Clean-up Project demonstrated that having only one $\mathrm{Hg}$ value without differentiating the approach towards industrial and residential areas may seriously impact a successful and timely implementation of remediation measures. The two-step approach 
suggested by Loring and Duffy (2011) based on a risk-benefit model seems most appropriate here. Kazakhstan, like many other former Soviet republics, inherited its environmental legislation mainly from the Soviet period when strict, inflexible reference values were equated with sound environmental protection. The economic and human dimensions, however, were omitted. The consulting team of the Nura Project, in order not to increase the cost of the project, had to apply to the Ministry of the Environment Protection of the Republic of Kazakhstan with a request to accept a reference value suitable for non-residential areas. This approach is now similar to variable criteria values of toxic substances in different countries and among some of the American states. Considerable variations of implementation can be explained by the numerous local conditions that formed a values determination output to develop workable and enforceable criteria.

Because of rapid and ill-planned industrial development during the Soviet era, there are many contaminated areas in Kazakhstan. Besides the Nura River $\mathrm{Hg}$ contamination, there were other $\mathrm{Hg}$ contaminated areas such as in Pavlodar city on the site of a chemical factory. The Pavlodar Chemical Factory used to produce chlorine and caustic soda $(\mathrm{NaOH})$ by the electrolysis method (Swartz, et al, 1994) with the use of mercury-pool cathode. Mercury removal work in Pavlodar is now underway. One of the aspects of that project was the initiation of the factory-monitoring laboratory which was a monitoring program after $\mathrm{Hg}$ clean-up in the northern industrial area in Pavlodar city over 15 years (2005-2020) (Ilyushchenko et al., 2010). In addition, in Ust-Kamenogorsk city, located in eastern Kazakhstan, there are deposits of complex ores including heavy metals. Stockpiled areas of mercury such as lamps have been located in the city of Semey (Ilyushchenko et al., 2010).

\subsection{Resilience and Complimentary Policies}

Studies on resilience and change in complex systems have shown that the pace of change over time is not continuous. Socio-ecological change shows patterns of stability and disturbance which are followed by reorganization and growth. Phenomena tend to be patchy and discontinuous on temporal and spatial scales (Allen and Holling, 2008). This pattern will lead to a certain amount of uncertainty always present, making management of social ecological systems difficult. Management policies can reduce vulnerability by enhancing adaptive capacity.

Remediation projects are a form of mitigation which reduces the exposure to potential hazards. Pollution monitoring, nutritional intervention and social support systems like education are also a necessary part of a robust mitigation program. All of these, along with stakeholder input, were part of the Nura River project. The project also enhanced the adaptive capacity by an adaptive management approach which was flexible in that flexibility can reduce the impact of uncertainty. The change in governance and revised criteria and policies while the project was underway enhanced the resilience of the system. Best management is not fixed but must develop modifications learned from past experience (Figure 4). 


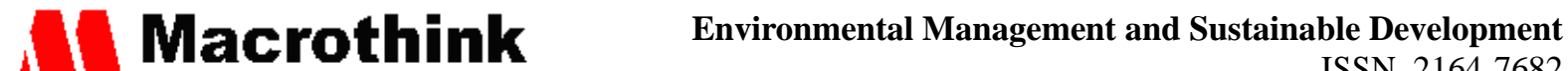

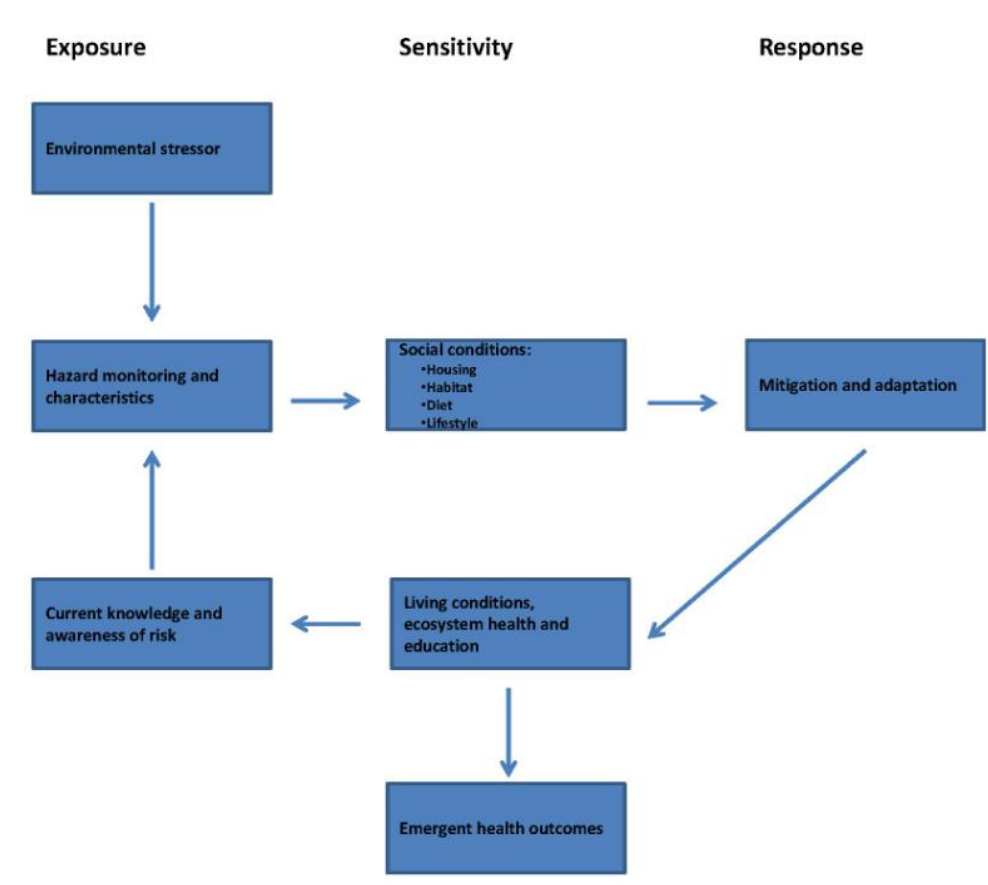

Figure 4. An adaptive systems approach connects exposure, sensitivity, and response

\section{Conclusion and Recommendations}

The Nura River Project was successfully completed in 2011, and the official closure occurred in 2012. However, the path to achieve the project's goals was not easy. For example, the climatic conditions restricted the operating time; the mobilization phase was longer than expected. Nevertheless, the goal of the Project was achieved - the mercury contamination was reduced to criteria levels and quality control was maintained during the entire realization phase. The Nura Project case is a good example of extended investigations using adaptive management and supporting a sense of environmental justice by stakeholder input. The scientific input, engineering work, and efforts offered by the project stakeholders had all contributed to the long waited and successful lowering of potential $\mathrm{Hg}$ exposure via water or the food chain.

\section{Acknowledgements}

We would like to thank the Muskie Foundation and the World Bank for supporting this work. We would additionally like to acknowledge the helpful discussions of the engineers and officials who were involved in the project.

\section{References}

Allen, C.R., \& C.S. Holling. (2008). Discontinuities in Ecosystems and Other Complex Systems: New York, NY: Columbia University Press.

Burger, J., Gochfeld, M., Powers, C.W., Kosson, D.S., Halverson, J., Siekaniek, G., Morkill, A., Patrick, R., Duffy, L.K. \& Barnes, D. (2007). Scientific research, stakeholders and policy: 
continuing dialogue during research on radionuclides on Amchitka Island, Alaska. Journal of Environmental Management, 85, 232-244. http://dx.doi.org/10.1016/j.jenvman.2006.10.005

Chapin, F.S., III, G.P. Kofinas, \& C. Folke (2009). Principles of Ecosystem Stewardship: Resilience-Based Natural Resource Management in a Changing World. Springer, New York. ISBN 978-0-387-73032-5.

Dunlap, K.L., Reynolds, A.J., Gerlach, S.C., \& Duffy, L.K. (2011). Mercury interferes with endogenous antioxidant level in Yukon River subsistence-fed sled dogs. Environmental Research Letters, 6, 044015. http://dx.doi.org/10.1088/1748-9326/6/4/044015

Commission Regulation. (2006). Setting maximum levels for certain contaminants in foodstuffs. Offical journal of the European Union, L364/20

Gleick, P., Wolff, G.H., \& Cooley H. (2007). The World's Water. Chicago, IL: The Pacific Institute.

Gunderson, L.H., \& Holling C.S. (2002). Panarchy: Understanding Transformations in Human and Natural Systems. Island Press, Washington, DC.

Ilyushchenko, M.A., Yakovleva, L.V., Kuzmenko, L.V., \& Kamberov, R.I. (2010). Management of mercury contamination and its monitoring in Pavlodar city, Republic of Kazakhstan. Final Project Technical Report. Non-profit JSC Almaty University of Power Engineering and Telecommunications.

Loring, P., Duffy, L., \& Murray, M. (2010). A risk-benefit analysis of wild fish consumption for various species in Alaska reveals shortcomings in data and monitoring needs. Science of the Total Environment, 408, 4532-4541. http://dx.doi.org/10.1016/j.scitotenv.2010.07.013

Loring, P. \& Duffy, L. (2011). Managing Environmental Risks: the benefits of a place-based approach. Rural and Remote Health, 11, 1800.

Maxwell, N. (2009). Understand Environmental Health. James and Bartlett Publishers, Boston.

Manahan, S. (1999). Industrial Ecology. Lewis Publishers, Boca Raton.

Manahan, S. (2011). Water Chemistry. CRC Press, Boca Raton.

Posch \& Partners Consulting Engineers, Intergeo, Bauer und Mourik Umwelttechnik, and Atasu Central Asian Consulting Company. (2005). Design of River Nura Mercury Clean-up. Final Design Report. Committee for Water Resources.

Posch and Partners (2009). Design of Reconstruction and Technical Re-equipment of the Yntumak Reservoir. Explanatory Note, 1. Corrected according to the comments and suggestions of the "Gosexpertisa" RSE dated May 25, 2007.

Schwartz, A., Bunce, D., Silberman, R., Stanitski, C., Stratton, W., \& Zipp, A. (1994). Onondaga Lake: A case study. In Chemistry and Context. Edition 1. Wm. C. Brown Publishers, Dubuque. 


\section{Macrothink}

Trainor, S., Godduhn, A., Duffy, L., Chapin, III.,F.S., Natcher, D., Kofinas, G., et al. (2009). Environmental Injustice in the Canadian Far North: persistent organic pollutants and Arctic climate impacts. In: Agyeman J., et al (Eds) Speaking for ourselves: environmental justice in Canada. University of British Columbia Press, Vancouver.

Watters, K. (2009). The fight for community justice against Big Oil in the Caspian Region: the case of Berezokva Kazakhstan. Environmental Justice and sustainability in the Former Soviet Union (Aquyerman, J. \& Oqneva-Himmelberger, Eds) MIT Press, 153-188.

Yen, T.F. (1999). Environmental Chemistry: Essentials of Chemistry for Engineering Practice. Prentice-Hall International, 4. London.

\section{Copyright Disclaimer}

Copyright reserved by the author(s).

This article is an open-access article distributed under the terms and conditions of the Creative Commons Attribution license (http://creativecommons.org/licenses/by/3.0/). 